\title{
ERROR CORRECTION IN A COMMUNICATIVE LANGUAGE TEACHING FRAMEWORK
}

$$
\text { Dr M.S. Odendaal }
$$

University of Stellenbosch

\section{INTRODUCTION}

The problem that I would like to address in this paper, is, I am convinced, experienced by all second language teacher trainers and teachers. In presenting the Communicative Approach and the theory on which it is founded, the data firmly guide them towards the conclusion that error is not the bête noire of language teaching but an integral part of the acquisition process. Then, when they teach the application of the theory in the classroom, and come to the evaluation of language proficiency, they are uncomfortably aware of retracting and contradicting much that they have said before.

To describe the anomaly I will attempt to

1. sketch the theory on which communicative language teaching is founded, referring simultaneously to research which supports the theory

2. look briefly at research on the salience of error correction

3. $100 k$ at the evaluation of language proficiency as it is practised in the school system

4. point out what kind of linguistic research is urgently required to solve the dilemma of second language teachers. 


\section{THEORY UNDERPINNING COMMUNICATIVE LANGUAGE TEACHING}

I will therefore briefly sketch the theoretical underpinnings of the communicative language teaching approach, as I present it. We usually start by looking, among others, at:

1.1 first language and second language acquisition theory

1.2 Interlanguage theory

1.3 the role of affect in the acquisition.process.

\subsection{FIRST LANGUAGE AND SECOND LANGUAGE ACQUISITION THEORY}

In the first place, although the Behaviourist view of language and language acquisiticn, viz, that language is acquired by stimulus-response conditioning, is rejected, we make students aware of the fact that some of its ghosts still haunt second language classrooms, viz, its insistence on the faultless model, on the elimination and prevention of error for fear that it should be reinforced, internalized and perpetuated.

We then proceed to some of the claims of Mentalist theory which, according to Ellis (1985), have radically changed our understanding of language acquisition and established a credible framework from which it can be studied:

1. Language exists as an independent faculty in the human mind i.e. although it is part of the learner's total cognitive apparatus, it is separate from the general cognitive mechanisms. 
2. The primary determinant of first language acquisition is the child's acquisition device, which is genetically endowed and provides the child with a set of principles about grammar.

3. The process of acquisition consists of hypothesis-testing, by which means the grammar of the learners' mother tongue is related to the principles of the universal grammar.

4. Interaction between the child's innate cognitive capacity and the language environment leads to universals.

5. Many of the child's early utterances are unique, therefore not imitated but generated.

6. Development is continuous and incremental but could be characterized as a series of stages.

7. The learner's language is systematic at each of these stages.

8. There is a natural order for language acquisition (E11ts 1985).

During the 60s, longitudinal studies by developmental psycholinguists O'Neill (1970) and Brown (1973) produced support for the theory of an innate device. They found that, irrespective of the input received, there is a more or less fixed sequence of development through which children pass on the way to achieving adult competence in their first language. For example, initially, their utterances consist of one word. Later two-word, then three and four-word phrases follow. Their knowledge of the grammatical system is built up in steps and in the same order, for example 
- they acquire word-order rules first

- omit grammatical morphemes such as articles and the concord "s" (Brown 1973)

- they learn grammatical markers after nouns and verbs before those betore nouns and verbs (S1obin 1971).

Which confirms Chomsky's notion that the human brain is not a receptacle filled by parents or teachers. Its structure guides the way children learn and internalize language.

The imrediate question is how much of this theory applies to second language acquisition? And equally importantly, is the language acquisition device still working?

The two arguments against its continued functioning are, in the first. place, the indeterminate amount of success achieved by adult second language learners, compared to the almost unfailing success of first language learners; secondly, Lenneberg's thests that the language acquisition device atrophies with the lateralization of the brain hemispheres during puberty (Ellis 1985). That debate is, however, beyond the scope of this paper. I believe that what Chomsky said about first language acquisition, viz, "It is impossible to understand how children master a language in so short a time in spite of the highly abstract nature of its rules and the irregularities and deficiencies of everyday speech", applies equally, to second language acquisition. Particularly, in view of the differences in the situation, motivation and age of the learners, as the table below indicates, it is incredible that a system of such complexity can be mastered without some innate assistance. 
DIFFERFNCES BETWEEN $\mathrm{L}_{1}$ AND $\mathrm{I}_{2}$ ACQUISITION

$\mathrm{L}_{1}$

$\mathrm{L}_{2}$

1. Functions of $\mathrm{L}_{1}$ : (Stander : 1967)

Means of communication

thought

development

sensory refinement

expressing emotion

being educated.

2. Because of functions (1), intense intrinsic motivation.

W11l become so after years.

Discrepancy between level of

thought and level of $\mathrm{L}_{2}$ - causes

frustration. Explores by means of

Has $\mathrm{L}_{1}$

Does so in $\mathrm{L}_{1}$

Does so in $\mathrm{L}_{1}$.

Because of functions (1), slight or no motivation - extrinsic.

3. Exposure to language:

14 hrs daily from birth.

Acquires language by 4 yrs.

$2^{1 / 2}$ hrs a week; from 6 yrs.

After 12 yrs, often has not

acquired it.

4. Environment in which acquired.

Mostly loving, warm environment of home.

Child rewarded for every effort.

Impersonal, critical, disapproving environment of school

Error emphasized, 11ttle reward for attempts to speak.

5. Developmental stage of learning 2 languages

$L$ synchronizes with developmental stage - in exploratory phase, discovering environment.

Thought operations simple, preoperationa1, suited to language.

Doesn't synchronize.

When he learns $\mathrm{I}_{2}$ he is in concrete operational phase. Can conceptualize, classify and serialize. Can't do it in $\mathrm{L}_{2}$. Thought processes far ahead of $\mathrm{L}_{2}$ proficiency.

6. No Interference for $L_{1}$

llas no other language to revert to which can interfere with the new language syster.

7. LAD functions optimaily.

Possibly less active.

8. Kind of Learning. incidental, subconscious learning intentions focused on communicating, getting needs satisfled, not language learning but acquisition.

Conscious intentional learning language learning. 
http://spilplus.journals.ac.za/

The following qualities of first language acquisition also apply to second language acquisition, viz,

- Many of the learner's early utterances are unique, therefore generated, not imitated.

- Development is continuous and incremental, but could be characterized as a series of stages.

- The learner's language is systematic at each of these stages. As we shall see in a moment - these theses express interlanguage theory in a nutshell.

Research on the natural order for first language acquisition was followed by a number of second language acquisition studies (EIIis i985). LongitudinaI studies by Ravem (1968) Cazden et al (1975) Wode (1980) Butterworth and Hatch (1978) and Schumann (1979) cover the second language acquisition of English by mother tongue speakers of Japanese, German and Norwegian. The learners included children, adolescents and adults. The focus was on the development of grammatical subsystems such as negation, interrogation and relative clauses in the interlanguage of the subjects. From this data considerable similarity in the development of negation, interrogatives and relative clauses was found.

Ellis (1985) finds that the order was not totally invariable across studies. Two morpheme studies by Dulay and Burt (1973, 1974) claimed that the acquisition order of child learners were the same, irrespective of their mother tongues. Baily et al (1974) had similar findings for adult learners. Larsen-Freeman (Ellis 1985), however, found that the accuracy order varied according to the elicitation 1nstrument used. Krashen (1977) again, replicated the studies and in general, found that the 
acquisition order for various gramatical functors is more or less the same, irrespective of the subjects' language backgrounds, their age and the language skills tested.

Ellis (1985) also maintains that the ranking procedure disguised the fact that some morpheme scores differed marginally, while others were far apart. To accommodate this, Dulay and Burt (1974) grouped the morphemes together to reflect a developmental stage: e.g.

Grammatical features acquired

Stage 1

Case

Word order

Nominative/Accusative

However, enough evidence was found that second language learners progress along an interlanguage continuum in a fairly similar way. On this basis, it can be claimed that, as first language learners have a natural order of acquisition, so do second language learners. In other words, the processes of acquisition and, by implication, the functioning of the brain implementing the processes, would be similar to some extent.

Which brings us to a brief look at Interlanguage theorp.

\subsection{INTERLANGUAGE THEORY}

The term was first used by Selinker in 1972. Nemser (1971) spoke of approxamitive systems, Corder (1967) of idiosyncratic dialects. By interlanguage they signified the following: (Ellis 1985) 
http://spilplus.journals.ac.za/

1. the learner uses a structured system at any stage of his/her development

2. the approximative systems form a series of interlocking systems through which the learner develops along an interlanguage continuum

3. at any given time the approximative system is different from first language and second language

4. the approximative systems of learners at the same stage of proficiency roughly coincide

5. the concept of "hypothesis testing" explains how the learner progresses along the Interlanguage continuum in much the sane way as it was used to explain First Language acquisition.

\section{INTERLANGUAGE THEORY PRESENTS A DIFFERENT VIEW OF ERROR}

Corder (1967) claimed that both first language and second language learners make errors in order to test out certain hypotheses about the nature of the target language. Corder saw the making of errors as a strategy, evidence of learner-internal processing.

Selinker terms adults' failure to reach target language competence i.e. when their interlanguage still contains some rules different from those of the target language system, fossilization i.e. when a developmental stage has been reached where a language feature will no longer change.

Selinker and Lamendella (1978b) maintain that fossilization occurs when the learner believes that he/she does not need to 
develop his/her target language any further, or when the operation of hypothesistesting mechanisms in the brain are restricted by age. Schumann (1976) and Smith (1972), looking at the process from a sociolinguistic perspective, say that language serves a restricted function for many second language speakers viz the transmission of referential, denotative information i.e. a communicative function, not an integrative one, in which the use of the language marks the speaker as a member of a group.

Hughes (1983) rejects Selinker's thesis that fossilization is due to cognitive incapacity. Looking at the research of Schumann (1978) and Smith (1972), he ascribes fossilization to sociolinguistic factors. Learners pass through similar mistakes in each developmental stage, "sloughing off" error as they enter another stage. Fossilization occurs when this movement through levels of interlanguage ceases, because the learner has acquired enough language to satisfy his/her needs, according to Schumann's pidginization hypothesis (Schumann 1978).

Hughes suggests several conditions under which learners keep moving from one interlanguage level to the next, and under which errors disappear natura11y:

1. the learner continues to have unsatisfied communicative needs

2. the learner continues to communicate

3. the situations in which he/she attempts to comunicate are sufficiently frequent

4. he/she understands at least some of the language when he/she communicates. (1983)

If one considers Schumann's (1976) hypothesis that integrative motivation, i.e. the desire to be accepted by, regarded as native 
speakers, is the force that keeps second language acquisition going, and fossilization from setting in, it seems that the teacher's inain function with respect to error, is to keep the process of moving through interlanguage levels and of shaking off errors, going.

\subsection{THE AFFECTIVE FILTER}

This hypothesis of Krashen (1982) has been least sniped at by linguists. He maintains that if the student becomes afraid or self-conscious about using the second language, his/her affective filter goes up and successfully prevents any language input.

A neurologist, Leslie Hart (Dhority 1984), describes the result of fear on the brain as follows: "Complex, creative learning is due to the evolution of the cerebrum, the most recent part of the brain. under threat, the brain down shifts, and faster-acting, simpler brain-resources take larger roles."

Barbara Clark (1986) adds, "Under stress the neocortex, the most complex system begins shutting down, turning over more and more functions to the limbic system brain. While rote learning can be continued, higher and more complex learning is inhibited."

Lozanov (1978), the Bulgarian psychiatrist and. founder of Suggestopaedia, claims that "relaxed attention and freedom from fear" is the ideal state for learning, and makes it a principle in the use of his method. Indeed, this principle is so firmly established in educational psychology that it should not be necessary to say more about it.

For the purposes of this paper, the one aspect of second language acquisition that causes the greatest inhibition and fear is 
error - and particularly overt error correction. Students find it humiliating and become too afraid to attempt using the language. And language USE is accepted in communicative language teaching as an essential condition for acquisition. Further, overt error correction creates a negative attitude towards the language and Krashen reports a positive correlation between attitude and acquisition. (Krashen 1982)

Let me summarize briefly what deductions re error we have arrived at from theory:

1. Language acquisition is not merely the result of imitating, repeating and memorising correct chunks of language.

2. It is directed by the learner's innate cognitive mechanisms which facilitate the discovery of the structure of the target language.

3. These mechanisms also direct the course the acquisition will take, irrespective of the input the teacher makes.

4. The language the learners use, is at al1 times systematic the deviant forms or errors form part of their system of interlanguage.

5. Error plays an important role in the process of hypothesis testing - it elicits the feedback that confirms or modifies the learners' hypotheses.

6. The learner moves at his/her own pace from one level of interlanguage to the next, shedding errors as he/she proceeds - again irrespective of the teacher's explanations or teaching. 
http://spilplus.journals.ac.za/

In other words, errors play an integral role in language acquisition - they do not only prove that acquisition is taking place, they are indispensible in the process. The teacher's explanations and corrections do not seem to affect the acquisition process of the pupils and their shedding of errors drastica11y.

Let us look next at research, testing the validity of these assumptions.

\section{RESEARCH ON ERROR CORRECTION}

Research on error correction focused first on whether error correction has an effect on second language acquisition. Robb, Ross and Shortreed (1986) report an attempt by Hendrickson (1972) to control error gravity by employing Burt and Kiparsky's (1972) global and local error taxonomy, but both treatments resulted in insignificant reduction of errors. In 1982 Lalande found that students who used an error code when revising their compositions made significantly greater gains than a group whose compositions were corrected directly by the instructor. Semke (1984) found that overt correction of student writing tended to have negative effects on both the quality of subsequent compositions and on student attitudes towards writing in the target language.

Robb, Ross and Shortreed (1986) subsequently describe an investigation into the merits of indirect and direct feedback. They compared four types of error treatment - each of which provided the second language learners with progressively less salient revisions in their compositions. Four groups of 33 Japanese students wrote 5 essays under carefully controlled conditions. The variable that was manipulated was the type of feedback the learners received. Group A's papers were completely corrected by the instructor and students had to copy their 
compositions, incorporating the instructor's corrections. Group B's compositions were marked in an abbreviated code system, in which the type of error was indicated, and students used a guide to decipher the markings. For Group $C$, the uncoded feedback group, errors on forms in need of editing were marked with a yellow text-marking pen but no explanation for, or identification of the marking, was supplied. For the marginal feedback group the number of errors per line was written in the margin but no further information was provided.

The Iesults support the afore-mentioned research on error correction. In general the more direct methods of feedback do not tend to produce results commensurate with the amount of effort required from the instructor to draw the students' attention to surface errors. Rather, practice in writing over time resulted in gradual increases in the mean scores of all four. groups, regardless of the method of feedback they received (Hendrickson 1987).

The investigators conclude that the study does not support the practice of direct correction of surface error. Negligible differences were found among the groups on most of the criterion measures. The fact that students in all the groups used more complex structures as the course progressed, indicates that improvement was independent of the type of feedback.

Robbits (1977) investigated the effectiveness of eliciting explanations of incorrect verb forms produced by English second language students. Eight intermediate English second language learners were randomly placed into a control group or an experimental group. For one trimester the experimental subjects were given a weekly error explanation session where they located their errors, corrected them and gave an explanation for each error. The control group got other kinds of feedback. Robbins 
found that the experimental technique was ineffective in reducing the frequency of student verb errors.

Hendrickson (1976, 1977) conducted experiments to determine what effects direct teacher correction would have upon English second language students' communicative and linguistic proficiency. He found that supplying the correct lexical forms and grammatical structures of students' errors had no statistically significant effect upon the writing proficiency of either high or low commicative groups of students.

\section{CONCLUSIONS}

To sum up what we have been saying: the theory underpinning communicative language teaching shows that error is an integral part of the acquisition process. Secondly, the teacher's input seems to have little effect on the pupils' shedding of eirors.

The research data confirms what theory hypothesizes. Little evidence can be found that error correction affects the learners' progress through the interlanguage levels.

\section{APPLICATION}

The logical application of such theory would be to tell teacher trainees: "Do not concentrate on errors, that is not your task. Increase the amount of comprehensible input and drastically increase USE."

However, teacher trainers are confronted by the demands of an educational system and a classroom situation in which students will have to function and where they will be expected to evaluate written output as follows: mark the errors, indicate in the margin what kind of error it is, then subtract one mark for each 
http://spilplus.journals.ac.za/

grammatical error and half a mark for a spelling or punctuation error up to a maximum of $X$.

The following written work evaluation grid illustrates what I have been saying, viz that in the school system error is to a large degree the main indicator of proficiency.

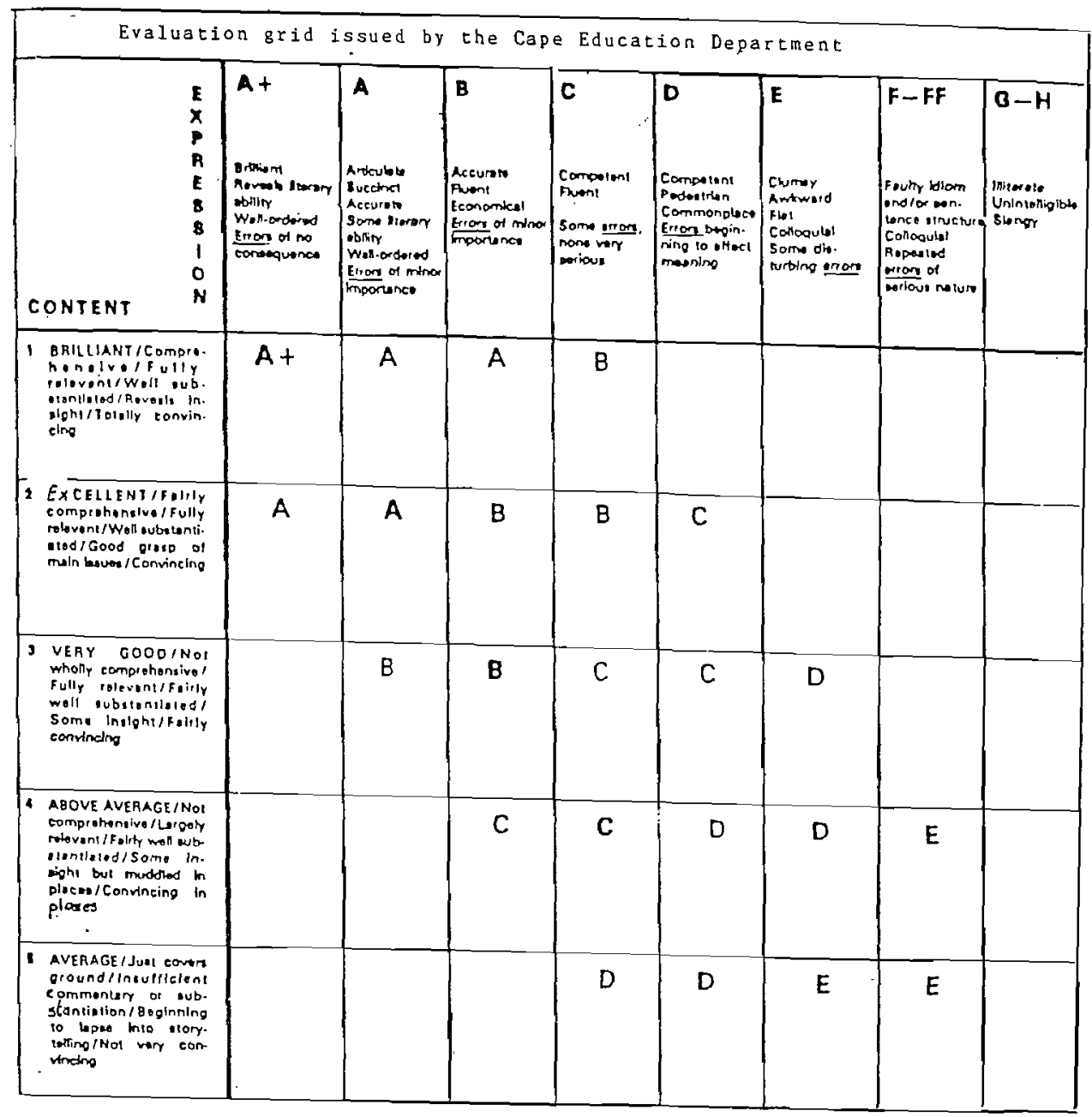


http://spilplus.journals.ac.za/

124

Furthermore, no guidance is given as to which errors are "serious" or "basic". Most teachers would agree that verb/subject concord is a "serious" error, although it is not a kind of error that impedes cominuication at all, which should be one of the chief criteria for the seriousness of error. Finally, it is futile to train teachers to pay less attention to error correction if it is regarded as the main indicator of proficiency. Teachers teach what is tested.

\section{REQUESTS FOR LINGUISTIC RESEARCH}

The crying need for communicative second language teaching, therefore, is to find indicators, other than error, to evaluate language proficiency, There have been several attempts of that kind. Word counts have been used; mean length of utterance is frequently used as an index of development. This is usually calculated by counting the number of morphemes in a given corpus and dividing it by the total number of utterances (El1is 1985). Other suggestions that might be investigated are those of Schumann (1978) and Andersen (1981). They found that the developmental continum closely resembled the pidginization / depidginization continuua in which certain stages can be observed.

E11is (1984) idendifies four broad stages of development in the developmental progression observed in longitudinal studies. The first is characterized by a standard word order though it might not be the word order of the target language structure. For example, inter alia, learners will use rules that lead to external negation and non-inverted interrogatives. Utterances are also propositionally reduced. 
In the second stage of development the learner's propositions are expanded to include most of the constituents required (Ellis 1985)

In the third stage gramatical morphemes begin to be used systematically and meaningfully. In the fourth stage, complex sentence structures such as embedided clauses and relative clauses modifying the subject of the sentence, are acquired (E111s 1985).

Descriptions of this kind, similar to those of Dulay and Burt, of the natural order of acquisition, might provide teachers with a grid within which they could evaluate the developmental gains that pupils have made and not merely record the fossilizations or slips.

\section{BIBLIOGRAPHY}

Andersen, R. (ed.) 1981. New Dimensions in Second Language Acquisition Research. Rowley, Mass.: Newbury House.

Andersen, R. (ed.) New Dimensions in Second Language Acquisition Research. Rowley, Mass.: Newbury House.

Bailey, W. et a1. 1974. "Is there a "Natural Sequence" In Adult Second Language Learning?" Language Learning 24.

Blair, R. 1983. Innovative Approaches to Language Teaching. Rowley, Mass.: Newbury House.

Brown, R. 1973. A First. Language: The Rarly Stages. Cambridge, Mass.: Harvard University Press.

Burt, M. and C. Keparsky. 1972. The Gooficon: A Repair Manuel for English. Rowley, Mass.: Newbury House.

Burt, M., H. Dulay and E. Hernandez. 1973. Bilingual Syntax Measure. New York: Harcourt Brace Jovanovich.

Butterworth, and E. Hatch. 1978. "A Spanish-speaking Adolescent's Acquisition of English Syntax" in E. Hatch (ed) Second Language Acquisition. Rowley, Mass.: Newbury House. 
Cazden, C. 1972. Child Language and Education. New York: Holt, Rinehart and Winston.

Clark, B. 1986. Optimizing learning. Columbus, Ohio: Merri11 Publishers.

Cohen, A.D. and M. Robbins. 1976. Interlanguage Performance: 1976. Towards Assessing Interlanguage Perlormance: the Relationship between Selected Errors, Learners' Characteristics and Learners' Explanations", Language Learning 26.

Corder, S. 1967. "The Significance of Learners' Errors" International Review of Applied Linguistics V.

Dhority, L. 1984 . Acquisition through Creative Teaching. Sharon: Mass.: Center for Continuing Development.

Dulay, H. and M. Burt and S. Krashen. 1982. Language Two. New York: Oxford University Press.

Dulay, H. and M. Burt, 1974. "Natural Sequences in Second Language Learning", Language Learning 24.

El1is, R. 1984. Classroom Second Language Development. Oxford: Pergamon.

E11is, Rod. 1985. Understanding Second Language Acquisition. Oxford, OUP.

Hendrickson, J. 1987. "Error Correction in Foreign Language Teaching: Recent Theory, Research and Practica" in $M$. Lang and J. Richards (eds) Methodology in TESOL; a Book of Readings.

Hughes, A. 1983. Second Language Learning and Communicative Language Teaching in $\mathbb{R}$. Johnson and $D$. Porter (eds) Perspectives in Communicative Teaching New York: Acaderic Press.

Krashen S. and M. Robbins. 1976. Toward Assessing Interlanguage Performance: The relationship between Selected Errors, Learner Characteristics and Learner Expectations. Language Learning 26.

Krashen, S. 1977. "Some Issues relating to the Monitor Mode1" in H. Brown, C. Yorio and R. Crymes (eds) ON TESOL 77. Washington, DC: TESOL.

Krashen, S, 1982. Principles and Practice In Second Language Acquisition. New York: Pergamon Press. 
Lalande, J.F. Reducing Composition
Experiment. Modern Language Journal 66.

Errors:

An

Lenneberg, E. 1967. Biological Foundations of Language. New York, Wiley and Sons.

Lozanov, G. 1978. Suggestology and Outlines of Suggestopedy. New York: Gordon and Breach.

O'Nei11, D. 1970. The Acquisition of Language. New York: Harper Row.

Nemser, W. 1971. "Approximative systems of Foreign Language Learners." International Review of Applied Linguistics XVI.

Ravem, R. 1968. 'Language Acquisition in a Second Language Environment.' International Review of Applied Linguistics VI.

Robb, T. S. Ross and I. Shortreed. 1986. "Salience of Feedback on Error and Its Effect on EFL Writing Quality." TESOL QUARTERLY Vo1 20 No 1 .

Schuman, J. 1979. "The Acquisition of English Negation by Speakers of Spanish: a Review of the Literature" in Andersen, R. (ed) The Acquisition and Use of Spanish and English as First and Second Languages. Washington DC, TESOL.

Schumann, J. 1976. "Second Language Acquistiton Research: Getting a more Global Look at the Learner in H. Brown (ed) Papers in Second Language Acquisition. Language learning. Special Issue 4.

Schumann, J. 1978, The Pidginization Process: A Model for Second Language Acquisition. Rowley, Mass.: Newbury House.

Semke, H.D. 1984. "The effects of the Red Pen." Foreign Language Annals, 17 .

Slobin, D. 1973. "Cognitive Requests for the Development of Grammar" in C. Ferguson and D. Slobin (eds). Studies of Child Language Development. New York: Holt, Rinehart and Winston.

Smith, D. 1972. Some Implications for the Social Status of Pidgin Languages" in D. Smith and R. Shur (eds) Sociolinguistics in Cross-Cultural Analysis. Washington, DC. Georgetown Univ. Press. 
Stander, P. 1967. Inleiding tot die Taalpsigologie, Stellenbosch. Universiteits Uitgewers en Boekhandel.

Wode, H. 1980. Learning a Second Language: An Integrated View of Language Acquistion. Tübingen: Gunter Navv. 